\title{
Impacts of vinasse and methods of sugarcane harvesting on the availability of $K$ and carbon stock of an Argisol
}

\author{
Claudinei Alberto Cardin ${ }^{1}$, Carlos Henrique dos Santos ${ }^{2 *}$, Marcos Antonio Escarmínio ${ }^{3}$
}

10.1590/0034-737X201663010013

\begin{abstract}
Soils of tropical regions are more weathered and in need of conservation managements to maintain and improve the quality of its components. The objective of this study was to evaluate the availability of $\mathrm{K}$, the organic matter content and the stock of total carbon of an Argisol after vinasse application and manual and mechanized harvesting of burnt and raw sugarcane, in western São Paulo. The data collection was done in the 2012/2013 harvest, in a bioenergy company in Presidente Prudente/SP. The research was arranged following a split-plot scheme in a $5 \times 5$ factorial design, characterized by four management systems: without vinasse application and harvest without burning; with vinasse application and harvest without burning; with vinasse application and harvest after burning; without vinasse application and harvest with burning; plus native forest, and five soil sampling depths (0-10 10-20, 20-30, 30-40, 40-50 cm), with four replications. In each treatment, the $\mathrm{K}$ content in the soil and accumulated in the remaining dry biomass in the area, the levels of organic matter, organic carbon and soil carbon stock were determined. The mean values were compared by Tukey test. The vinasse application associated with the harvest without burning increased the K content in soil layers up to $40 \mathrm{~cm}$ deep. The managements without vinasse application and manual harvest after burning, and without vinasse application with mechanical harvesting without burning did not increase the levels of organic matter, organic carbon and stock of total soil organic carbon, while the vinasse application and harvest after burning and without burning increased the levels of these attributes in the depth of $0-10 \mathrm{~cm}$.
\end{abstract}

Key words: soil fertility, organic matter, straw, leaching.

\section{RESUMO}

\section{Impactos da vinhaça e formas de colheita da cana-de-açúcar na disponibilidade de K e no estoque de carbono de um Argissolo}

Solos de regiões tropicais são mais intemperizados e necessitam de manejos conservacionistas para manter e melhorar a qualidade dos seus componentes. O objetivo desta pesquisa foi avaliar a disponibilidade de $\mathrm{K}$, o teor de matéria orgânica e o estoque de carbono total de um Argissolo, diante da aplicação de vinhaça e da colheita manual e mecanizada de cana, queimada e crua, no oeste paulista. A coleta de dados ocorreu na safra 2012/2013, em uma empresa de bioenergia de Presidente Prudente, SP. Utilizou-se o delineamento em parcelas subdivididas, em esquema fatorial 5x5, caracterizado pelos manejos (sem aplicação de vinhaça e com colheita sem queima; com aplicação de vinhaça e com colheita sem queima; com aplicação de vinhaça e colheita com queima; sem aplicação de vinhaça e colheita com queima; mata nativa), cinco profundidades de amostragem de solo (0-10, 10-20, 20-30, 30-40, 40-50 cm), em quatro repetições. Nas amostras foram determinados o teor de $\mathrm{K}$ do solo e o acumulado na biomassa seca remanescente na

\footnotetext{
Submitted on 05/11/2015 and approved on 10/01/2015.

${ }^{1}$ Universidade do Oeste Paulista, Programa de Pós-Graduação em Agronomia, Presidente Prudente, São Paulo, Brasil. cardin@unoeste.br

${ }^{2}$ Universidade do Oeste Paulista, Programa de Pós-Graduação em Agronomia, Presidente Prudente, São Paulo, Brasil. chenrique@unoeste.br

${ }^{3}$ Universidade do Oeste Paulista, Presidente Prudente, São Paulo, Brasil. ma.escarminio@bol.com.br

* Corresponding author: chenrique@unoeste.br
} 
área, os teores de matéria orgânica, carbono orgânico e o estoque de carbono do solo. As médias dos resultados foram comparadas pelo teste de Tukey. A aplicação de vinhaça associada à colheita sem queima incrementou o teor de $\mathrm{K}$ das camadas de solo até $40 \mathrm{~cm}$ de profundidade. Os manejos sem a aplicação de vinhaça e colheita manual com queima e sem a aplicação de vinhaça, com colheita mecanizada sem queima, não aumentaram os teores de matéria orgânica e de carbono orgânico e o estoque de carbono orgânico total do solo, enquanto a aplicação de vinhaça e colheitas com queima e sem queima aumentaram os teores destes atributos, na profundidade de 0-10 cm.

Palavras-chave: fertilidade de solo, palhada, matéria orgânica, lixiviação.

\section{INTRODUCTION}

Sugarcane has great socio-economic and political importance to Brazil. Its production has been growing in recent years, driven by factors such as external demand for sugar, domestic consumption of alcohol as motor vehicle fuel and addition of anhydrous ethanol to fossil fuels, with the aim, among others, to reduce the emission of pollutants.

The area cultivated with sugarcane, harvested and destined for sugar and ethanol activity in the 2013/14 season, was $8,810,150$ hectares, spread over all the producing states, according to their characteristics. Sao Paulo remains the largest producer, with $51.66 \%$ of the planted area (Conab, 2012).

However, the removal of natural forest for the introduction and expansion of agriculture promotes numerous changes in the soil, especially in the availability of nutrients and organic matter. These changes may impact some soil attributes responsible for root growth, water infiltration and water movement in the soil, soil gas exchange, biological activity and carbon mineralization, which are partly related to the soil properties and physical processes (Burger \& Kelting, 1999).

A major challenge in the tropics is to develop crop production systems that can maintain high productivity and environmental sustainability. In general, in these agroecosystems, there is a predominance of very weathered soils, which require conservation managements to maintain and improve the quality of the components of the medium (Pignataro Netto et al., 2009).

In this sense, within the sugarcane production system, the importance of applying vinasse results not only from the large volume where it is generated, but also from the economy of inputs, which are obtained with the practice of their use in the form of fertilizer or soil conditioner (Tasso Jr. et al., 2007). However, in view of the high levels of nutrients such as $\mathrm{K}, \mathrm{Ca}, \mathrm{Mg}$, and mainly organic material, the use of vinasse as fertilizer must not exceed the water retention capacity of the soil when applied in large amounts. Otherwise, leaching of several of these elements can occur, particularly $\mathrm{K}$, which can achieve subsurface waters (Silva et al., 2007).
In sandy soils, the organic matter is an essential component to improve water and nutrient retention and, consequently, to reduce the harmful effects of leaching. The topography of the areas occupied by sugarcane plantations in São Paulo allows about 60\% of the planted area to be amenable to mechanized harvesting (Gonçalves, 2002). This allows mechanized and manual harvesting to coexist and, therefore, collaborates intensively to increase the disposal of organic waste in the soil surface.

The objective of this research was to monitor the impacts of the vinasse application and manual (burned cane) and mechanical harvesting forms (raw cane) in the levels of potassium and organic matter and the influence in the stock of total carbon of a dystrophic Red-Yellow Argisol, in the western region of São Paulo.

\section{MATERIAL AND METHODS}

Management data were obtained in the 2012/2013 harvest in an agricultural production area of a company in the bioenergy sector in Ameliópolis, district of Presidente Prudente, SP, located at $21^{\circ} 51^{\prime} 57^{\prime \prime}$ S (latitude), $51^{\circ} 15^{\prime} 35^{\prime \prime} \mathrm{W}$ (longitude) and altitude of 329.35 meters.

The regional climate is Aw, according to the Koppen international climate classification, with rainfall and average annual temperature of $1858.7 \mathrm{~mm}$ and $25.5^{\circ} \mathrm{C}$ in 2012 , and $1633.6 \mathrm{~mm}$ and $24.8^{\circ} \mathrm{C}$ in 2013 , respectively.

The management areas destined to the evaluation have soil classified as Red-Yellow Argisol (Embrapa, 2013), whose sieve analysis (Embrapa, 1997) indicates the average levels of 840, 55 and $105 \mathrm{~g} \mathrm{~kg}^{-1}$ sand, silt and clay, respectively, at a depth of $0-25 \mathrm{~cm}$, and 793, 62 and $145 \mathrm{~g}$ $\mathrm{kg}^{-1}$ sand, silt and clay, respectively, at a depth of 25-50 $\mathrm{cm}$. To obtain these values, four simple samples were taken in each area at depths of 0-25 and 25-50 cm, and mixed to obtain a composite sample of each depth. Later, in face of the similar values of sand, silt and clay, the average values of these granulometric fractions were obtained.

The evaluations were made in management areas of the cultivar RB867515 in the third cut, due to its regional dominance and strong presence in all the areas that had the managements proposed for the study. Its cultivation, intense in the western region of São Paulo, is highlighted 
by the high adaptive capacity to hot and dry climate, low to medium fertility soil, and the rapid growth and median productivity of stems.

Evaluations of soil characteristics were carried out following the experimental design in split-plots in a factorial $5 \times 5$, having the managements considered as the plots and the depths as sub-plots, with four replications. The four managements adopted for sugarcane and the control were the first factor and the five soil sampling depths, the second. The first factor consisted of: A) WVWD: sugarcane area without application of vinasse (WV) and with mechanical harvesting /without burning (WB); B) RVWB: Sugarcane receiving vinasse application (RV) and mechanical harvesting/without burning (WB); C) RVAB: Sugarcane receiving vinasse application (CV) and manual harvesting after burning (AB); D) WVAB: Sugarcane without vinasse application (WV) and manual harvesting after burning (AB); E) Remaining native forest area (NF). The areas A, B, C and D show, respectively, 8.7; $8.4 ; 4.2 ; 5.2$ ha and sugarcane cultivation in the last 20 years. The remaining NF covers an area of 10.2 ha.

In 2009, prior to planting, the company held the soil sampling at depths of $0-25$ and $25-50 \mathrm{~cm}$, following the methods described by Raij et al. (2001), for the chemical characterization and establishment of lime and fertilizer doses. Thereafter, every year, soil analyzes in the same depths were held before doing soil liming and fertilization. The areas managed without application of vinasse received the standard fertilization of $400 \mathrm{~kg} \mathrm{ha}^{-1}$ of $05-26$ $30\left(120 \mathrm{~kg} \mathrm{ha}^{-1}\right.$ of $\left.\mathrm{K}_{2} \mathrm{O}\right)$.

Other cultural practices such as control of pests, diseases and weeds were made by the company, according to the needs presented. All areas managed with vinasse received 60.96 (2010); 71.13 (2011); 92.48 (2012) and 83.33 $\mathrm{m}^{3} \mathrm{ha}^{-1}$ (2013). The volumes were calculated according to the content of $\mathrm{K}$ found in the soil.

Data collection was conducted in March 2013, after the third sugarcane cutting, in the previously defined and georeferenced areas.

The determinations of $\mathrm{K}$ levels and organic matter (SOM) were performed in deformed soil samples collected at 0-10, 10-20, 20-30, 30-40 and 40-50 cm, in four trenches, made in the dimensions of 50 (L) x 30 (W) x $80 \mathrm{~cm}$ (D), spaced $50 \mathrm{~m}$ in the study areas. Two simple samples were collected in all depths, one on each side of the trench, and mixed for a representative composite sample for each depth. In total, 100 samples were subjected to K extraction by ion-exchange resin, whose quantification was performed by the atomic absorption spectrophotometry method (Raij et al., 2001) in the equipment model AA200, PerkinElmer. The SOM was extracted by Walkley-Black method, also described in Raij et al. (2001), and quantified by the colorimetric method, by spectrophotometer
FEMTO, model 600 Plus. Subsequently, the SOM content was converted to soil organic carbon (SOC) with the application of Van Bemmelen factor based on the assumption that the soil organic matter contains $58 \%$ organic C.

The stock of total organic carbon (STC) was calculated as the equivalent mass of soil (Elbert \& Bettany, 1995), from the collection of undisturbed samples, according to the following equation: STC $\left(\mathrm{Mg} \mathrm{ha}^{-1}\right)=\{$ Content of $\mathrm{C} \mathrm{x}$ Tx SD $\}$, where $\mathrm{C}=$ value in $\mathrm{g} \mathrm{kg}^{-1}, \mathrm{~T}=$ layer thickness $(\mathrm{cm})$ and $\mathrm{SD}=$ soil density $\left(\mathrm{g} \mathrm{cm}^{-3}\right)$ in the layer. Subsequently, following the recommendation of Sisti et al. (2004), the STC of the management systems was fixed for the same soil mass, having the NF conditions as reference values.

To obtain the values of soil bulk density (SD), used to calculate the STC, two undisturbed samples at each depth were collected, one on each side of the trenches, totaling 200 samples. Sampling was carried out using stainless steel cylinders, with a volume of $92 \mathrm{~cm}^{3}$ coupled to the Uhland sampler.

In the same period of the soil sampling, sampling of straw (biomass) was also carried out in the soil surface. A sample of biomass was collected from each plot, using a wooden board with dimensions of $50 \mathrm{~cm}$ x $50 \mathrm{~cm}$, totaling 20 samples. The material was washed quickly with deionized water to remove the impurities in excess, and taken into an oven with forced air circulation, at $65^{\circ} \mathrm{C}$, to obtain constant mass. Subsequently, the quantification of dry matter biomass was performed (DMB) in semianalytical scale, with values estimated in $\mathrm{Mg} \mathrm{ha}^{-1}$.

The $\mathrm{K}$ content of DMB was determined in the same samples, following the extraction and elemental determination procedures, described by Malavolta et al. (1997). With this result, its accumulation in plant tissue was calculated, in function of the amount of DMB produced in each area.

The results were submitted to analysis of variance and means were compared by Tukey test at 5\% probability. The significance of the interaction among crop management factors and soil depths was verified by $\mathrm{F}$ test.

\section{RESULTS AND DISCUSSION}

The application of vinasse increased soil exchangeable $\mathrm{K}$ content in managements RVWB and RVAB, and no significant difference was seen among depths sampled (Table 1). There was also no difference between the managements RVWB and RVWB, indicating that the harvesting method did not influence the availability of $\mathrm{K}$ to the soil. Samples collected in NF showed K levels equal to those of managements WVWB and WVAB (Table 1).

Although no significant differences were observed among the soil depths, there was a tendency to reduction 
of the K content towards the deeper layers (Table 1). Zolin et al. (2011) found a K movement between depths of 0-20 and $20-40 \mathrm{~cm}$ during 20 years of vinasse application, noting that the long application time intensified the displacement of the element in the profile.

Silva et al. (2014) also pointed out that the vinasse provided significant increase of $\mathrm{K}$ to $40 \mathrm{~cm}$ deep, in an Ortic Quartzarenic Neosol, though, in this same situation there was a reduction of exchangeable $\mathrm{K}$ content, in an average of 54.5 to $50.0 \%$, at $0-10$ and $20-40 \mathrm{~cm}$, respectively, from the first to the third cutting. According to the authors, this reduction was due to the lowering of the effect of potassium fertilization, performed at the planting of sugarcane. The K leaching is significant in sandy soils, which are characterized by having low effective CEC and low water retention capacity (Ernani et al., 2007). Furthermore, high rainfall rates may enable the displacement of $\mathrm{K}$ in the soil profile, reducing the levels of this nutrient in the surface layers, even in more clayey soils and with high CEC (Flores et al., 2012).

The content of $3.83 \mathrm{mmol}_{\mathrm{c}} \mathrm{dm}^{-3}$ of $\mathrm{K}$, found in management RVWB (Table 1), equivalent to the contribution of $298.8 \mathrm{~kg} \mathrm{ha}^{-1}$ of $\mathrm{K}$, would be suitable for the development of the crop, while the management RVAB added only $2.28 \mathrm{mmol}_{\mathrm{c}} \mathrm{dm}^{-3}$ of $\mathrm{K}$ to the soil, that is, 177.8 $\mathrm{kg} \mathrm{ha}^{-1}$. Ribeiro et al. (1999) and Silva et al. (2005) consider that the level of $150 \mathrm{mg} \mathrm{dm}^{-3} \mathrm{~K}$, equivalent to $300 \mathrm{~kg} \mathrm{ha}^{-1}$ of $\mathrm{K}$ in the soil, meets the nutritional requirements of sugarcane.

The difference in the $\mathrm{K}$ content in the soil between the managements RVWB and RVAB is associated with the harvesting method of sugarcane. The soil of the RVWB area showed higher content of $\mathrm{K}$ (Table 1), and in this situation, the sugarcane enabled the accumulation of 7.74
Mg ha-1 DMB (Table 2), demonstrating, therefore, the cycling potential of $20.93 \mathrm{~kg} \mathrm{ha}^{-1}$ of $\mathrm{K}$ throughout the crop cycle. The biomass accumulation in management RVAB was $0.33 \mathrm{mg} \mathrm{h}^{-1} \mathrm{DMB}$ and the potential for future addition of $\mathrm{K}$ to the soil was only $1.19 \mathrm{~kg} \mathrm{ha}^{-1}$ (Table 2).

The cycling potential of $\mathrm{K}$, accumulated in the DMB deposited on the soil surface (Table 2) may contribute satisfactorily to increase its availability. According to Carvalho et al. (2013), there can have significant increase in the availability of $\mathrm{K}$ at $0-20 \mathrm{~cm}$ after one-year management with vinasse, highlighting, however, that the presence of this element may also be partly attributed to its availability by the decomposition of the remaining straw. Despite being a material of high $\mathrm{C} / \mathrm{N}$ ratio (Cantarella, 1998) and therefore, showing slow mineralization rate, Oliveira et al. (1999) observed that K, for being soluble in the plant tissue, was the chemical element with the fastest release (93\% in average) by the sugarcane biomass.

The $\mathrm{K}$ contents in the DMB of WVWB and WVAB areas showed no statistical difference when compared to the RVWB and RVAB areas (Table 2). DMB production of the WVWB and WVAB areas was 7.1 and $1.3 \mathrm{t} \mathrm{ha}^{-1}$, respectively, and the contribution potential of $\mathrm{K}$ to the soil was of 12.6 and $4.0 \mathrm{~kg} \mathrm{ha}^{-1}$, respectively (Table 2). Besides the burning management, which reduces the deposition of biomass to the soil surface, it is important to note that the difference in biomass production is also associated with the differentiation in the production of stem between the mentioned areas. The productivity of the WVWB area was 53.0 $\mathrm{Mg} \mathrm{ha}^{-1}$ while the management WVAB was $31.8 \mathrm{Mg} \mathrm{ha}^{-1}$. However, the amount of DMB produced in all these areas was generally lower than the average $13.3 \mathrm{t} \mathrm{ha}^{-1}$ year $^{-1}$, reported by Luca et al. (2008).

Table 1: Potassium (K) contents in the managements and depths assessed. Presidente Prudente. SP

\begin{tabular}{lcc}
\hline Management & $\mathbf{K}\left(\mathbf{m m o l}_{\mathbf{c}} \mathbf{d m}^{-3}\right)$ & Increase of $\mathbf{K}$ in relation to the $\mathbf{N F}(\%)$ \\
\hline WV WB & $0.48 \mathrm{c}$ & - \\
WVAB & $0.59 \mathrm{c}$ & - \\
RVWB & $3.83 \mathrm{a}$ & 580.3 \\
RVAB & $2.28 \mathrm{~b}$ & 345.5 \\
MN & $0.66 \mathrm{c}$ & - \\
\hline Depth $(\mathbf{c m})$ & & Percentage of $\mathbf{K}$ in relation to 0-10 cm depth \\
\hline $0-10$ & $2.14 \mathrm{a}$ & 100.0 \\
$10-20$ & $1.72 \mathrm{a}$ & 80.4 \\
$20-30$ & $1.53 \mathrm{a}$ & 71.5 \\
$30-40$ & $1.26 \mathrm{a}$ & 58.9 \\
$40-50$ & $1.19 \mathrm{a}$ & 55.6 \\
\hline CV $(\%)$ & 76.76 & - \\
LSD & 1.06 & -
\end{tabular}

Means followed by the same letter do not differ by Tukey test at $5 \%$ probability. LSD = least significant difference. WVWB: without vinasse without burning; WVAB: without vinasse after burning; RVWB: receiving vinasse without burning; RVAB: receiving vinasse after burning; NF: native forest.

Rev. Ceres, Viçosa, v. 63, n.1, p. 095-102, jan-fev, 2016 
The importance of the contribution of vinasse in providing $\mathrm{K}$ for the cultivation of sugarcane is noticeable (Table 1), and the negative impact of the reduction of the remaining DMB in sandy soils by the action of fire is also clear. This reduction in DMB supply, observed in the WV areas, due to the burning, was approximately $6.0 \mathrm{Mg} \mathrm{ha}^{-1}$ (Table 2), but Resende et al. (2006) point out that, with the burning, up to $10 \mathrm{Mg} \mathrm{ha}^{-1}$ year $^{-1} \mathrm{DMB}$ may be lost, and thus, significant loss of C, N, K. Straw burning speeds up the mineralization of nutrients in the soil, among which $\mathrm{K}$ stands out. However, the rapid entry into the system may also favor its leaching, especially in soils with low CEC. Resende et al. (2006) agree with this information and stress that the total availability of $\mathrm{K}$ in the soil also favors its rapid uptake by plants.

The agricultural management studied did not differ in SOM levels, observing only a difference when comparing the contents of different managements with the contents of NF (Table 3). However, there was significant interaction among the managements and the sampled soil depths.

Even after three years of cultivation, management RVWB, which provided greater DMB intake on the soil surface, did not significantly increase the SOM (Table 3). The sandy texture plus chemical and biological characteristics of the soil made possible the rapid degradation of SOM over time, not allowing its significant accumulation. In tropical areas, it is difficult to increase the organic matter content in sandy soils and this shows that the change of land use, with the removal of native vegetation and the introduction of crops such as sugarcane, quickly reduces SOM content (Table 3), reflecting negatively on soil quality. This practice has a great significance, because the content and quality of SOM can be directly used to assess the sustainability of agricultural systems (Mielniczuk, 1999).

The suppression of burning with the maintenance of straw on the soil results in higher concentration of SOM (Graham et al., 2002), but the degradation of this material can still be fast. Experiments performed in sugarcane fields in Brazil show that the effect of DMB maintenance often occurs in clayey (Orlando Filho et al. 1998) and medium- texture soil (Souza et al., 2005), but not in very sandy soils (Ball-Coelho et al., 1993). According to Alexander (1977), in regions of high temperatures, with excessive soil mobilization, subjected to constant burning, drastic reduction of SOM contents occurs.

Besides the DMB, which can remain in the mechanical harvesting systems of raw sugarcane, vinasse is also a source of organic matter to the soil, although the managements RVWB and RVAB, for three consecutive years, have not been effective in supporting the increase of the SOM content (Table 3). Corroborating the data presented in Table 3, Andrioli (1986) did not observe alteration of SOM content after applications of up to 1200 $\mathrm{m}^{3} \mathrm{ha}^{-1}$ vinasse, in a Latosol cultivated with sugarcane. However, the author pointed out that the preservation of DMB and the frequent addition of vinasse are important strategies for maintaining and/or to increase soil fertility in the long run. According to Camilotti et al. (2006), vinasse adds SOM, but the effects are transitory.

In managements WVWB and WVAB, there was no differentiation of SOM contents among the soil layers. In RVWB and RVAB areas, the SOM content was on average $1.5 \mathrm{~g} \mathrm{dm}^{-}{ }^{3}$ greater than the managements WVWB and WVAB, although not statistically different, but enabled, in the treatment with vinasse, the SOM content of the layers 0-10 and 0-20 cm to be statistically higher than the ones of deeper layers (Table 3 ). In NF, the MOS content of 0-10 cm was higher than the $10-20 \mathrm{~cm}$ layer. In the other depths, there was no significant difference (Table 3 ).

A similar trend was observed for SOC because changes of SOM content directly imply impacts on the contents of this parameter (Table 3). Despite not having been observed difference in SOC content among the management areas, there was a significant interaction of these with the depths studied (Table 3).

The managements WVWB, WVAB, RVWB and RVAB indicate that the application of vinasse and harvesting methods for three years, were not enough to increase the SOC content in the soil (Table 3). However, the managements RVWB and RVAB showed differences in SOC content among depths (Table 3). At 0-10 cm, the

Table 2: Straw potassium (K) content, dry matter biomass (DMB) and accumulation of $\mathrm{K}$ in the DMB in the managements assessed

\begin{tabular}{|c|c|c|c|}
\hline Management & $\mathrm{K}\left(\mathrm{g} \mathrm{kg}^{-1}\right)$ & DMB $\left(\right.$ Mg ha $\left.^{-1}\right)$ & K accumulation $\left(\mathrm{kg} \mathrm{ha}^{-1}\right)$ \\
\hline WVWB & $2.07 \mathrm{~b}$ & $7.05 \mathrm{~b}$ & $12.59 \mathrm{~b}$ \\
\hline WVAB & $3.00 \mathrm{ab}$ & $1.25 \mathrm{c}$ & $3.95 \mathrm{c}$ \\
\hline RVWB & $2.72 \mathrm{ab}$ & $7.74 \mathrm{~b}$ & $20.93 \mathrm{~b}$ \\
\hline RVAB & $3.52 \mathrm{ab}$ & $0.33 \mathrm{c}$ & $1.19 \mathrm{c}$ \\
\hline $\mathrm{NF}$ & $3.75 \mathrm{a}$ & $12.4 \mathrm{a}$ & $45.23 \mathrm{a}$ \\
\hline $\mathrm{CV}(\%)$ & 22 & 32 & 23 \\
\hline LSD & 1.47 & 4.02 & 8.40 \\
\hline
\end{tabular}

Means followed by the same letter do not differ statistically. WVWB: without vinasse without burning; WVAB: without vinasse after burning; RVWB: receiving vinasse without burning; CVCQ receiving vinasse after burning; NF: native forest. 
management RVWB showed an average increase of $60 \%$ of the SOC content as compared with the group of 30-40 and $40-50 \mathrm{~cm}$ depths. In RVAB areas, the average content of SOC was on average $72.7 \%$ higher, compared to the 30 40 and $40-50 \mathrm{~cm}$ layers. Probably, the rapid mineralization of the SOM, forced by the burning, in the management RVAB, increased the SOC content as compared with the RVWB. There was no significant difference between these levels at depths of 0-10, 10-20 and 20-30 cm.

The difficulties of providing increases in SOM and SOC are also associated with moving and preparing the soil for cultivation, which favor the oxidation reactions in face of the increase of the partial pressure of oxygen and the exposure of new surfaces for microbial attack. The net balance of this effect is the reduction of SOM content, on systems with more intensive soil preparation. More conservative systems tend, over time, to provide a SOM increment on the soil surface (Freixo et al., 2002). In a straw management experiment in sugarcane areas, installed 59 years ago in South Africa, Graham et al. (2002) found that the SOC contents increased in layers sampled up to $10 \mathrm{~cm}(0-2.5,2.5-5.0$ and 5-10 cm), and the greater effect was in the first layer, whose $\mathrm{C}$ content reached $43 \mathrm{~g} \mathrm{~kg}^{-1}$, in the management of burnt cane, and $55 \mathrm{~g} \mathrm{~kg}^{-1}$, in areas without burning.
In Brazil, Canellas et al. (2003) analyzed the effect of 35 years of raw and burnt sugarcane managements and observed an increase of 70 and $77 \%$ of SOC, at 0-20 and $20-40 \mathrm{~cm}$ layers, respectively, over time. They also found significant increases in SOC content in the soil of 17 and $11 \%$ at $0-20$ and $20-40 \mathrm{~cm}$, respectively, in the area of sugarcane cultivation with vinasse. Still according to the authors, although low, average increases of $14 \%$ of SOC are not negligible for tropical soils, where it is difficult to increase the SOM content.

The STC also was not significantly modified between the agricultural managements WVWB, WVAB, RVWB, RVAB and depths, but there was interaction between both (Table 3). By contrast, in NF area the STC was superior to the other areas, showing the negative impact of agricultural activity on this chemical attribute of soil.

The STC in the set of areas WVAB + RVAB and WVWB + RVWB ranged between 7.3 and $7.6 \mathrm{Mg} \mathrm{ha}^{-1}$, considering the $0-20 \mathrm{~cm}$ soil layer, indicating no significant increase in the STC in the soil after three years of managements. Yet, Luca et al. (2008) found STC between 20 and $24.5 \mathrm{Mg} \mathrm{ha}^{-1}$, among the areas with and without burning, respectively, after four years without burning of sugarcane, in a dystrophic Red-Yellow Argisol in northeast of Sao Paulo state.

Table 3: Soil organic matter contents (SOM), soil organic carbon (SOC), in $\mathrm{g} \mathrm{dm}^{-3}$ and total carbon stock (STC), in Mg ha ${ }^{-1}$, considering the interaction between the managements and the soil depths evaluated.

\begin{tabular}{|c|c|c|c|c|c|}
\hline \multirow{3}{*}{ Management } & \multicolumn{5}{|c|}{ Soil Organic Matter (SOM) } \\
\hline & \multicolumn{5}{|c|}{ Depth $(\mathrm{cm})$} \\
\hline & $0-10$ & $10-20$ & $20-30$ & $30-40$ & $40-50$ \\
\hline SV SQ & $9.55 \mathrm{bA}$ & $7.55 \mathrm{bA}$ & $6.95 \mathrm{aA}$ & $6.67 \mathrm{aA}$ & $6.60 \mathrm{aA}$ \\
\hline SV CQ & $9.47 \mathrm{bA}$ & $8.70 \mathrm{bA}$ & $8.30 \mathrm{aA}$ & $6.93 \mathrm{aA}$ & $6.75 \mathrm{aA}$ \\
\hline CV SQ & $10.58 \mathrm{bA}$ & $9.15 \mathrm{bAB}$ & $7.45 \mathrm{aAB}$ & $6.53 \mathrm{aB}$ & $6.73 \mathrm{aB}$ \\
\hline CV CQ & $11.83 \mathrm{bA}$ & $10.07 \mathrm{bAB}$ & $9.75 \mathrm{aAB}$ & $7.20 \mathrm{aB}$ & $6.55 \mathrm{aB}$ \\
\hline NF & $29.00 \mathrm{aA}$ & $16.50 \mathrm{aB}$ & $9.15 \mathrm{aC}$ & $7.77 \mathrm{aC}$ & $6.85 \mathrm{aC}$ \\
\hline \multicolumn{6}{|c|}{ Soil Organic Carbon (SOC) } \\
\hline SV CQ & $5.55 \mathrm{bA}$ & $4.40 \mathrm{bA}$ & $4.00 \mathrm{aA}$ & $3.87 \mathrm{aA}$ & $3.85 \mathrm{aA}$ \\
\hline SV SQ & $5.52 \mathrm{bA}$ & $5.05 \mathrm{bA}$ & $4.57 \mathrm{aA}$ & $4.02 \mathrm{aA}$ & $3.90 \mathrm{aA}$ \\
\hline CV SQ & $6.15 \mathrm{bA}$ & $5.32 \mathrm{bAB}$ & $4.35 \mathrm{aAB}$ & $3.77 \mathrm{aB}$ & $3.90 \mathrm{aB}$ \\
\hline CV CQ & $6.87 \mathrm{bA}$ & $5.85 \mathrm{bAB}$ & $5.10 \mathrm{aAB}$ & $4.15 \mathrm{aB}$ & $3.82 \mathrm{aB}$ \\
\hline $\mathrm{NF}$ & $16.85 \mathrm{aA}$ & $9.60 \mathrm{aB}$ & $5.32 \mathrm{aC}$ & $4.52 \mathrm{aC}$ & $4.00 \mathrm{aC}$ \\
\hline \multicolumn{6}{|c|}{ Carbon Stock (STC) } \\
\hline SV SQ & $7.36 \mathrm{bA}$ & $5.88 \mathrm{bA}$ & $5.49 \mathrm{aA}$ & $5.50 \mathrm{aA}$ & $5.59 \mathrm{aA}$ \\
\hline SV CQ & $7.30 \mathrm{bA}$ & $6.50 \mathrm{bA}$ & $6.29 \mathrm{aA}$ & $5.72 \mathrm{aA}$ & $5.65 \mathrm{aA}$ \\
\hline CV SQ & $9.12 \mathrm{bA}$ & $7.84 \mathrm{bAB}$ & $7.01 \mathrm{aAB}$ & $5.92 \mathrm{aAB}$ & $5.53 \mathrm{aB}$ \\
\hline CV CQ & $8.17 \mathrm{bA}$ & 7.14 bA & $6.01 \mathrm{aA}$ & $5.34 \mathrm{aA}$ & $5.67 \mathrm{aA}$ \\
\hline $\mathrm{NF}$ & $22.48 \mathrm{aA}$ & $12.91 \mathrm{aB}$ & $7.31 \mathrm{aC}$ & $6.44 \mathrm{aC}$ & $5.81 \mathrm{aC}$ \\
\hline
\end{tabular}

$\overline{\mathrm{CV}}(\%)$ general = 20 (SOM); 20 (SOC) and 20 (STC); LSD for lines (capital letters) and columns (lowercase) = 3.72 (SOM); 2.14 (SOC) and 3.36 (STC). Equal letters, lowercase and uppercase letters in the column in the line, do not differ at 5\% probability by Tukey test. WVWB: without vinasse without burning; WBAB: without vinasse after burning; RVWB: receiving vinasse without burning; RVAB: receiving vinasse after burning; NF: native forest.

Rev. Ceres, Viçosa, v. 63, n.1, p. 095-102, jan-fev, 2016 
However, according to Graham et al. (2002), the clay content is an important factor to achieve significant increases in STC. Soils with clay content near $580 \mathrm{~g} \mathrm{~kg}^{-1}$ are capable of storing approximately $137 \mathrm{Mg} \mathrm{ha}^{-1}$ of $\mathrm{C}$ in the layer 0-30 cm, in the managements with and without burning. The $\mathrm{C}$ storage capacity of the soil is remarkable and highly dependent on the clay content. Studies have shown that, in relation to storages of a dystrophic Red Latosol, the C storage capacity was $52.6 \%$ for dystrophic Red-Yellow Argisol and 47.2\% for Ortic Quartzarenic Neosol (Luca et al., 2008). Therefore, sandy soils tend to have faster humification of SOM, due to their greater macroporosity, which promotes better conditions for aeration and increased activity of decomposer microfauna, reducing the STC (Luca et al., 2008).

Within this aspect, the low clay contents of the management areas studied, $105 \mathrm{~g} \mathrm{~kg}^{-1}$ in the $0-25 \mathrm{~cm}$ and $145 \mathrm{~g} \mathrm{~kg}^{-1}$ in the $25-50 \mathrm{~cm}$ layer, in contrast to the high content of total sand, $840 \mathrm{~g} \mathrm{~kg}^{-1}$, in the $0-25 \mathrm{~cm}$ layer, and $793 \mathrm{~g} \mathrm{~kg}^{-1}$ in the $25-50 \mathrm{~cm}$ layer, may have enabled the rapid decomposition of the SOM from the vinasse and the remaining DMB, hindering increases of SOC and STC and increases of SOC content and STC (Table 3).

\section{CONCLUSIONS}

The application of vinasse associated with the harvesting system without burning increased the concentration of $\mathrm{K}$ in the soil layers up to $40 \mathrm{~cm}$ depth.

The agricultural managements, without the application of vinasse, with manual harvesting after burning and without application of vinasse, with mechanical harvesting without burning did not increase the levels of solil organic matter, organic carbon and the stock of total soil carbon, while systems with vinasse application and harvest after burning or without burning increased the levels of these attributes only in the depth of $0-10 \mathrm{~cm}$.

\section{ACKNOWLEDGMENT}

To the technical staff of the bioenergy sector of the company, for the assignment of areas used for data collection and for logistical support. Special acknowledgment to the Universidade do Oeste Paulista, for the financial and infrastructure support to carry out the chemical analyzes.

\section{REFERENCES}

Alexander M (1977) Organic matter decomposition. In: Alexander M (Ed.) Introduction to soil microbiology. New York, John Willey. p.128-147.

Andrioli I (1986) Efeitos da vinhaça em algumas propriedades químicas e físicas de um Latossolo Vermelho-Escuro textura média. Tese de Doutorado. Escola Superior de Agricultura "Luiz de Queiroz", Piracicaba. 85p.
Ball-Coelho B, Tiessen H, Stewart JWB, Salcedo IB \& Sampaio EVSB (1993) Residue management effects on sugarcane yield and soil properties in northeastern Brazil. Agronomy Journal, 85:1004-1008.

Burger JA \& Kelting DL (1999) Using soil quality indicators to asses forest stand management. Forest Ecological Management, 122:155-166

Camilotti F, Andrioli I, Marques MO, Silva AR, Tasso Júnior LC \& Nobile FO (2006) Atributos físicos de um latossolo cultivado com cana-de-açúcar após aplicações de lodo de esgoto e vinhaça. Engenharia Agrícola, 26:738-747.

Canellas LP, Velloso ACX, Marciano CR, Ramalho JFGP, Rumjanek VM, Rezende CE \& Santos GA (2003) Propriedades químicas de um Cambissolo cultivado com cana-de-açúcar, com preservação do palhiço e adição de vinhaça por longo tempo. Revista Brasileira de Ciência do Solo, 27:935-944.

Cantarella H (1998) Aplicação de nitrogênio em sistema de canacrua. STAB - Açúcar, Álcool e Subprodutos, 16:21-22.

Carvalho JM, Andreotti M, Buzetti S \& Carvalho MP (2013) Produtividade de cana soca sem queima em função do uso de gesso e vinhaça. Pesquisa Agropecuária Tropical, 43:1-9.

Conab (2012) Acompanhamento de safra brasileira: cana-de-açúcar. Terceiro levantamento: safra 2011/ 2012. Disponível em: <http://www.conab.gov.br>. Acessado em: 10 de julho de 2013.

Elbert BH \& Bettany JR (1995) Calculation of organic matter and nutrients stored in soils under contrasting management regimes. Canadian Journal Soil Science, 75:529-538.

Embrapa (1997) Centro Nacional de Pesquisa de Solos. Manual de métodos de análises de solo. Rio de Janeiro, Centro Nacional de Pesquisa de Solos. 212p.

Embrapa (2013) Centro Nacional de Pesquisa de Solos. Sistema brasileiro de classificação de solos. $2^{\mathrm{a}}$ ed. Rio de Janeiro, Centro Nacional de Pesquisa de Solos. 353p.

Ernani PR, Almeida JA \& Santos FC (2007) Potássio. In: Novais RF, Alvarez VHV, Barros NF, Fontes RLF, Cantarutti RB \& Neves JCL (Eds.) Fertilidade do Solo. Viçosa, Sociedade Brasileira de Ciência do Solo. p.551-594.

Flores RA, Prado RM, Politi LS \& Almeida TBF (2012) Potássio no desenvolvimento inicial da soqueira de cana crua. Pesquisa Agropecuária Tropical, 42:106-111.

Freixo A, Machado PLOA, Guimarães CM, Dias CA \& Fadigas F (2002) Estoques de carbono e nitrogênio e distribuição de frações orgânicas de Latossolo do cerrado sob diferentes sistemas de cultivo. Revista Brasileira de Ciência do Solo, 26:425-434.

Gonçalves DB (2002) A regulamentação das queimadas e as mudanças nos canaviais paulistas. São Carlos, Rima. 127p.

Graham MH, Haynes RJ \& Meyer JH (2002) Soil organic matter content and quality: Effects of fertilizer applications, burning and trash retention on a long-term sugarcane experiment in South Africa. Soil Biology Biochemical, 34:93-102.

Luca EF, Feller C, Cerri CC, Barthés B, Chaplot V, Campos DC \& Manechini C (2008) Avaliação de atributos físicos e estoques de carbono e nitrogênio em solos com queima e sem queima de canavial. Revista Brasileira de Ciência do Solo, 32:789-800.

Malavolta E, Vitti GC \& Oliveira AS (1997) Avaliação do estado nutricional das plantas - princípios e aplicações. $2^{\text {a }}$ ed. Piracicaba, Potafos. 319p.

Mielniczuk J (1999) Matéria orgânica e sustentabilidade de sistemas agrícolas. In: Santos GA \& Camargo FAO (Eds.) Fundamentos da matéria orgânica do solo. Porto Alegre, Genesis. p.1-7.

Rev. Ceres, Viçosa, v. 63, n.1, p. 095-102, jan-fev, 2016 
Oliveira MW, Trivelin PCO, Gava GJC \& Penatti CP (1999) Degradação da palhada de cana-de-açúcar. Scientia Agricola, 56:803-809.

Orlando Filho J, Rosseto R, Muraoka T \& Zotelli HB (1998) Efeitos do sistema de despalha (cana crua $\mathrm{x}$ cana queimada) sobre algumas propriedades do solo. STAB-Açúcar, Álcool Subprodutos, 16:30-34.

Pignataro Neto IT, Kato E \& Goedert WJ (2009) Atributos físicos e químicos de um Latossolo vermelho-amarelo sob pastagens com diferentes históricos de uso. Revista Brasileira de Ciência do Solo, 33:1441-1448.

Raij BV, Andrade JC, Cantarella H \& Quaggio JA (2001) Análise química para avaliação da fertilidade de solos tropicais. Campinas, Instituto Agronômico. 285p.

Resende AS, Santos A, Xavier RP, Coelho CH, Gondim A, Oliveira OC, Alves BJR, Boddey RM \& Urquiaga S (2006) Efeito da queima da palhada da cana-de-açúcar e de aplicações de vinhaça e adubo nitrogenado em características tecnológicas da cultura. Revista Brasileira de Ciência do Solo, 30:937-941

Ribeiro AC, Guimarães PTG \& Alvarez VH (1999) Recomendações para o uso de corretivos e fertilizantes em Minas Gerais. $5^{\text {a }}$ aproximação. Viçosa, CFSEMG. 359p.

Silva APM, Bono JAM \& Pereira FAR (2014) Aplicação de vinhaça na cultura da cana-de-açúcar: Efeito no solo e na produtividade de colmos. Revista Brasileira de Engenharia Agrícola e Ambiental, 18:38-43.
Silva MAS da, Griebeler NP \& Borges LC (2007) Uso de vinhaça e impactos nas propriedades do solo e lençol freático. Revista Brasileira de Engenharia Agrícola e Ambiental, 11:108-114.

Silva AJN, Cabeda VSM \& Lima FWFJ (2005) Efeito de sistemas de uso e manejo nas propriedades físico-hídricas de um Argissolo Amarelo de tabuleiro costeiro. Revista Brasileira de Ciência do Solo, 29:833-842.

Sisti CPJ, Santos HP dos, Kohhann R, Alves BJR, Urquiaga S \& Boddey RM (2004) Change in carbon and nitrogen stocks in soil under 13 years of conventional or zero tillage in southern Brazil. Soil and Tillage Research, 76:39-58.

Souza ZM, Prado RM, Paixão ACS \& Cesarin LG (2005) Sistemas de colheita e manejo da palhada de cana-de-açúcar. Pesquisa Agropecuária Brasileira, 40:271-278.

Tasso Junior LC, Marques MO, Franco A, Nogueira GA, Nobile FO, Camilotti F \& Silva AR (2007) Produtividade e qualidade de cana-de-açúcar cultivada em solo tratado com lodo de esgoto, vinhaça e adubos minerais. Engenharia Agrícola, 27:276-283.

Zolin CA, Paulino J, Bertonha A, Freitas PSL \& Folegatti MV (2011) Estudo exploratório do uso da vinhaça ao longo do tempo. I. Características do solo. Revista Brasileira de Engenharia Agrícola Ambiental, 15:22-28. 